\title{
Somatic embryos from Phalaenopsis classic Spotted Pink (Orchidaceae) protocorms
}

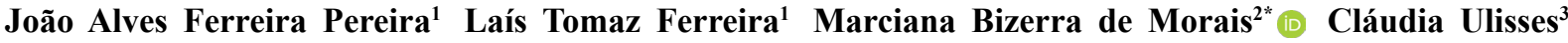

\author{
${ }^{1}$ Departamento de Agronomia, Universidade Federal Rural de Pernambuco (UFRPE), Recife, PE, Brasil. \\ ${ }^{2}$ Programa de Pós-graduação em Ciência Naturais (PPGCN), Universidade do Estado do Rio Grande do Norte (UERN), 59600-000, Mossoró, \\ RN, Brasil. E-mail: marciana.bio@gmail.com. "Corresponding author.
}

${ }^{3}$ Departamento de Biologia, Universidade Federal Rural de Pernambuco (UFRPE), Recife, PE, Brasil.

ABSTRACT: The aim of the present study was to induce the formation of somatic embryos in protocorms from Phalaenopsis Classic Spotted Pink hybrids at two physiological maturation stages, namely: 80 and 120 days after seed inoculation (DASI). Protocorms were inoculated in $1 / 2$

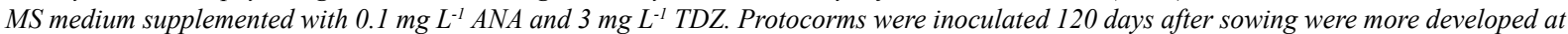
the $15^{\text {th }}$ cultivation day due to the formation of pro-embryogenic structures. It was possible seeing the formation of globular-and torpedo-stage somatic embryos at the $30^{\text {th }}$ day of cultivation in somatic embryogenesis (SE) induction medium. The protocorms inoculated at the $80^{\text {th }}$ DASI did not formed somatic embryos; they oxidized 20 days after cultivation in SE-induction medium. The formation of somatic embryos happened directly on the explant, thus characterizing a direct somatic embryogenesis. The embryos converted into plants when the somatic embryos were transferred to the nutrient medium containing no growth regulator. Therefore, it was concluded that the somatic embryos induction from protocorms 120 days after sowing was positive, since the embryos were able to become plants and presented vegetative organs with morphological traits similar to those of the matrix plant.

Key words: orchid, protocormoids, somatic embryogenesis.

Embriões somáticos provenientes de protocormos de Phalaenopsis classic Spotted Pink (Orquidaceae)

RESUMO: O presente estudo buscou induzir a formação de embriões somáticos em protocormos do híbrido Phalaenopsis Classic Spotted Pink em dois estádios de maturação fisiológica aos 80 e 120 dias após a inoculação das sementes (DAIS). Os protocormos foram inoculados

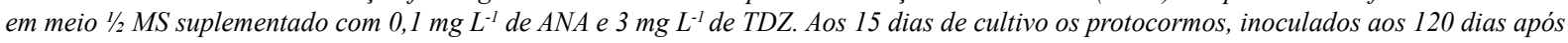
a semeadura, apresentavam estádio mais desenvolvido, apresentando formação de estruturas pró-embriogênicas. Aos 30 dias de cultivo em meio de indução de ES observou-se a formação de embriões somáticos na fase globular e torpedo. Os protocormos inoculados com 80 DAIS não evoluíram para a formação de embriões somáticos, ocorrendo a oxidação destes aos 20 dias após o cultivo em meio de indução de ES. A formação dos embriões somáticos ocorreu diretamente no explante, caracterizando uma embriogênese somática direta. Quando os embriões somáticos foram transferidos para o meio nutritivo sem regulador de crescimento, houve a conversão em plantas. Diante disso, conclui-se que a indução de embriões somáticos a partir de protocormos com 120 dias após a semeadura, foi positiva, em que os embriões obtidos apresentaram competência em converter-se em plantas, apresentando os órgãos vegetativos com características morfológicas satisfatórias. Palavras-chave: orquidea, protocormoides, embriogênese somática.

Orchids are perennial plants showing different sizes, as well as different stem, leaf and flower shapes. Orchids are remarkably well accepted in the floriculture market due to their ornamental features, durability, diversity and exuberance (FREITAS et al., 2014); thus, they have great economic importance. There has been increased production of seedlings from several orchid species and hybrids due to cultivation techniques applied in vitro in Brazil; consequently, large scale proliferation of healthy and disease free quality propagating material can be obtained with this technique. It has also been proved to be economically viable option for efficient biodiversity and gene pool conservation (SARMAH et al., 2017).

Phalaenopsis orchids are recognized as the most popular orchid genus in the horticultural industry due to their large, colorful, and durable flowers as well as their wider adaptability to room conditions (ZAHARA et al., 2017). This species has been widely investigated in the last decade due to the high demand for cut or pot flowers (PARK et al., 2015). This orchid has a high economic value both as cut flowers and as potted plants in international flower markets (GOW et al., 2010). Characteristics 
of seedlings propagated by vegetative means are not uniform; therefore, propagation through tissue culture is desirable (ZAHARA et al., 2017). They are monopodial, alternifolia plants showing vegetative meristem finishing. Their vegetative propagation is naturally slow and the formation of lateral sprout does not happen often, fact that hinders their propagation through conventional methods (NG \& SALEH, 2011).

The need of enabling the mass propagation of elite Phalaenopsis genotypes has encouraged the development of micropropagation studies. Multiplication of orchid hybrid clones is highly desirable and the cloning in vitro allows standardizing morphological traits such as flower size and shape, as well as physiological traits such as adaptation to environments suitable for floral stem emissions. In the sense, somatic embryogenesis is a method used in the production of new embryos from pre-existing somatic embryos. Embryogenic callus systems are highly regenerable and can generate large numbers of propagules and hold for long periods (MOURA et al., 2017).

The somatic embryogenesis induction appears as the possibility of using other plant regions or organs, as well as of producing large numbers of embryos from haploid or somatic cells in order to develop a complete plant, with higher genetic integrity when compared with plants regenerated through the process of organogenesis (GRANDO et al., 2013). In that process, somatic cell differentiates into a plant without involvement of fertilization or gamete fusion (SMERTENKO \& BOZHKOV, 2014).

Factors such as ontogenetic age of maternal tissue, hormonal levels, type of culture medium used, among others, interfere with the various stages of somatic embryo formation (MOURA et al., 2017). However, the selection of suitable types and sources of explant are critical factors for obtaining a successful culture in somatic embryogenesis system (FENG \& CHEN, 2014). In the sense, protocorm stage is featured by the development of the zygote embryo, which may be an explant used to induce somatic embryogenesis, since its structure has juvenile and meristematic tissues.

In light of the foregoing, the aim of the current study was to analyze the somatic embryogenesis induction in protocorms from the Phalaenopsis Classic Spotted Pink hybrid at two different physiological maturation stages, namely: 80 and 120 days after seed inoculation (DASI).

The study was conducted in the Plant Tissue Culture Laboratory at Federal Rural University of
Pernambuco, Recife County, Pernambuco State (PE) Phalaenopsis Classic Spotted Pink seeds removed from immature capsules were inoculated in glass vials $(250 \mathrm{~mL}$ capacity) holding $30 \mathrm{~mL}$ of MS basal culture medium containing half the concentration of salts supplemented with sucrose $\left(30 \mathrm{~g} \mathrm{~L}^{-1}\right)$, vitamins and agar $\left(6.5 \mathrm{~g} \mathrm{~L}^{-1}\right)$, after they underwent an asepsis process. Cultures were kept in a growth room at 25 $\pm 2^{\circ} \mathrm{C}$ and subjected to 16 -h photoperiods under 42 $\mathrm{mmol} \mathrm{m} \mathrm{m}^{-2} \mathrm{~s}^{-1}$ white fluorescent lamp irradiation.

The plant materials presenting morphological responses after 110 days were transferred to the somatic embryogenesis-induction stage. The regenerated protocorms from the Phalaenopsis Classic Spotted Pink hybrid were used as explants in this stage; they presented conical shape and green color, and were generated through asymbiotic germination; part of the protocorms was used at the $80^{\text {th }}$ DASI and the other part was used at the $120^{\text {th }}$ DASI. Then, the protocorms were inoculated in induction medium containing $0.1 \mathrm{mg}$ $\mathrm{L}^{-1}$ ANA $+3 \mathrm{mg} \mathrm{L}^{-1} \mathrm{TDZ}$, and gelled in $2.0 \mathrm{~g} \mathrm{~L}^{-1}$ gelrite. The medium $\mathrm{pH}$ was adjusted to 5.2 (CHEN $\&$ CHANG, 2006) before the medium was autoclaved at $121{ }^{\circ} \mathrm{C}$ for $20 \mathrm{~min}$.

Approximately 30 explants showing physiological ages 80 and 120 DASI were inoculated in test tubes containing $10 \mathrm{~mL}$ of the aforementioned nutrient medium and kept in the dark in a growth room at $25 \pm 2{ }^{\circ} \mathrm{C}$ in order to assess the somatic embryogenesis-induction period. The somatic embryos obtained after 30 days in the dark were transferred to a new test tube containing nutrient medium devoid of growth regulator. Next, they were subjected to 16 -h photoperiods to induce their conversion into seedlings. Morphological changes and/or embryos' formation were assessed at this stage.

Seed cultivation in MS medium containing no growth regulators has allowed differentiating the seeds in the protocorms, which were used as explants, from the $30^{\text {th }}$ day on. Orchid seeds have a tiny embryo, which develops when the seeds are under the influence of mycorrhizal fungi or when they are grown in the nutrient medium wherein the protocorm is formed (STEFANELLO et al., 2009). This result suggested that the endogenous hormone inside the explants might still have a role in embryo formation. Similar results were reported by MORADI et al., (2017) when they assessed the potential of different types of explant of Epipactis veratrifolia orchid. They reported that protocorm had the highest embryo induction frequency (100\% embryogenesis) among 
leaf segment, apical bud, single node, and crown. SEs were also formed from protocorm and stem explants when cultured on hormone-free medium.

The most important inducing agent in somatic embryogenesis (SE) is the growth regulator, mainly auxin, which presents satisfactory results in orchids supplemented with TDZ (CHEN \& CHANG 2006), and with the association between ANA and BAP (MINAMIGUCHI \& MACHADO NETO 2007). It has been already proven that ANA and BAP have not efficiently formed somatic embryos when they were used alone (MINAMIGUCHI \& MACHADO NETO, 2007). As for the current study, the first changes in the explants cultivated in vitro were observed at the $15^{\text {th }}$ cultivation day in the dark, after SE induction. Some protocorms at physiological age 120 DASI have formed pro-embryogenic structures, which showed rounded shape and translucent color (Figure 1A), whereas other protocorms at the same physiological age have shown leaf primordia with etiolation features; these protocorms have presented pro-embryogenic structures on their bases (Figure 1B). Pro-embryogenic structures showing the same features were also reported by CHEN and CHANG (2006) and by MINAMIGUCHI and MACHADO NETO (2007), when they induced somatic embryogenesis in Phalaenopsis amabilis leaves and in an alba flower hybrid, respectively.

The protocorms inoculated at the $80^{\text {th }}$ DASI did not form somatic embryos; they oxidized 20 days after cultivation in SE-induction medium. Protocorm darkening or necrosis followed by death is a common phenomenon in orchid cultivation in vitro. This phenomenon may be related to inappropriate cultivation conditions such as nutritional imbalance or to the lack of some stimulatory substance. However, the oxidation in the current study seemed to be related to the protocorm maturation stage.

There was significant pro-embryo development at the $23^{\text {th }}$ day of cultivation in SEinduction medium, as well as the formation of new morphogenic structures presenting globular shape

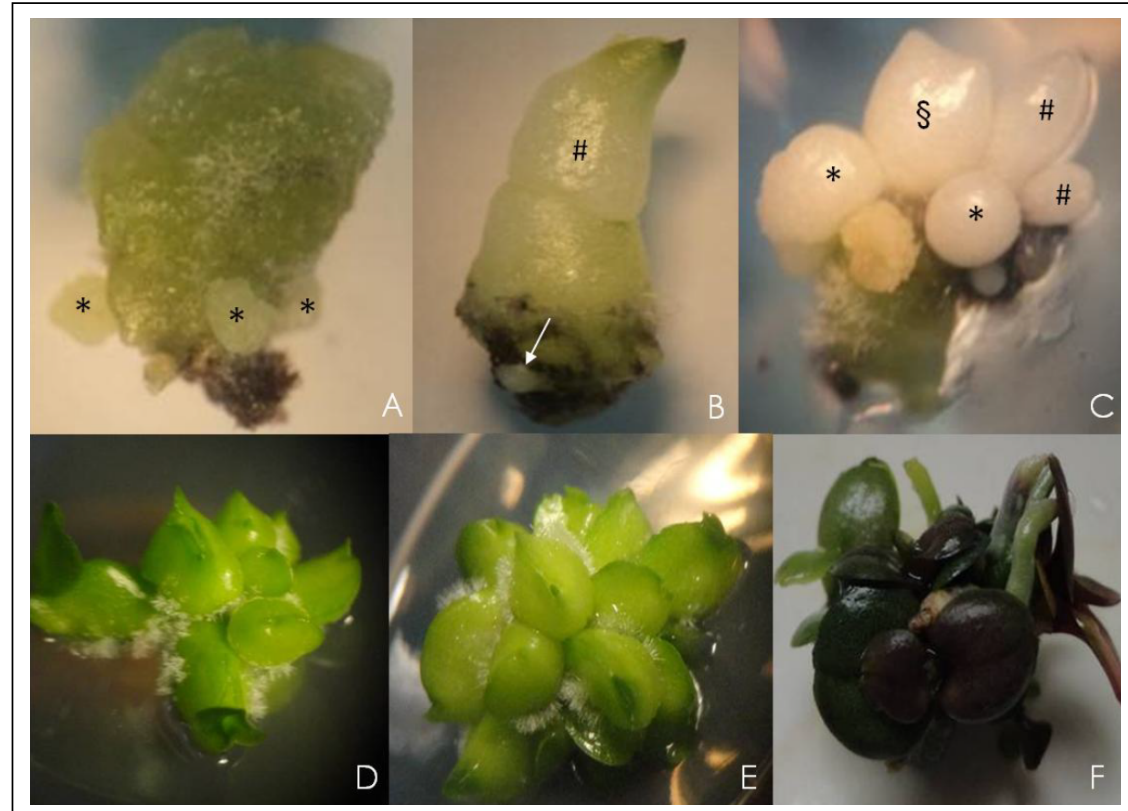

Figure 1 - Phalaenopsis Classic Spotted Pink hybrid development stages (at 120 DASI), in somatic embryos until complete plant: (A) Protocorm showing the formation of morphogenic structures at the explant base, 15 days after SE-induction; (B) Protocorm showing leaf primordia etiolation (\#) and morphogenic structure formation at the base (arrow) (20x); (C) Protocorm showing embryos in different stages at the 30th culture day: globular (*), Torpedo (\#) and protocormoids ( $($ ); (D and E) Chlorophyllated protocormoids from somatic embryos; (F) Complete plants derived from somatic embryos generated from protocorms. 
and whitish color. It was possible seeing embryo development-stage evolution at the $30^{\text {th }}$ day of cultivation under the aforementioned conditions, when somatic embryos were visualized in the following development stages: globular, torpedo and protocormoid formation onset, which is typical to orchids (Figure 1C). These somatic embryos have directly formed from the inoculated explant (protocorm), thus characterizing their direct origin, since callus formation was not observed.

Explants directly originating somatic embryos have embryogenic route-predetermined cells, because their constitution presents meristematic parental cells. It explains their trend to happen, preferably, in explants with embryonic tissues presenting adequate differentiation level. Therefore, protocorms showing embryonic tissues in their constitution present this competence and reach the expression stage, thus differentiating themselves as somatic embryos.

After the somatic embryos were formed, they were transferred to the conversion medium under light condition. It was possible seeing that, at the $20^{\text {th }}$ cultivation day under light condition, the embryos evolved to chlorophyll structures, similar to protocorms, and showed leaf primordia and hairs in the distal region (Figures 1D and 1E). It shows the importance of transferring the embryos of this Phalaenopsis hybrid to the nutrient medium devoid of growth regulators, and under light condition, in order to convert the protocormoids into plants; this stage was observed in the present study at the end of 90 cultivation days under light condition (Figure 1F).

MINAMIGUCHI and MACHADO NETO (2007) did not obtain regenerated plants from the somatic embryos formed in their study, since these embryos, and the nutrient medium, underwent phenolization; it may have happened because the embryos were kept in the induction medium containing ANA and BAP. Conversely, CHEN and CHANG (2006) have reported that the embryos' permanence in an inducing nutritional medium containing TDZ led to the formation of secondary embryos and; consequently, to the increased number of embryos per explant. The conversion of somatic embryos into plants is the last somatic embryogenesis stage and it happens in nutrient medium lacking (or not) growth regulators (VAN DER VYVER, 2010; BASNAYAKE et al., 2011).

Overall, the explant origin is one of the factors affecting the somatic embryogenesis induction. Most studies about somatic embryogenesis induction in orchids are conducted in leaves
(CHEN \& CHANG, 2006). However, the herein presented results have shown that protocorms are an excellent explant alternative to induce somatic embryogenesis, since it enables genetic diversity and later regeneration in plants, when it is performed under light condition and in a nutrient medium devoid of growth regulator. It was possible finding 7 somatic embryos, on average, and approximately 7 plants regenerated by protocorms inoculated under the aforementioned conditions.

Thus, according to the qualitative perspective, the herein described method may be considered effective and adequate to produce phenotypically uniform Phalaenopsis Classic Spotted Pink seedlings, in a relatively short time, from the protocorm-based induction of somatic embryos; the method may be also used in other species belonging to the same family. The propagation reported in the current study may be tested through the bioreactor system in order to enable the use of protocols in largescale productions, which allow meeting the consumer market demands and help reducing the extraction of individuals from natural environments. In addition, studies about Phalaenopsis propagation in vitro may also provide subsidies for studies about in vitro germplasm conservation.

\section{ACKNOWLEDGMENT}

The authors gratefully acknowledge the Universidade Federal de Pernambuco (UFRPE) for support.

\section{DECLARATION OF CONFLICT OF INTERESTS}

The authors declare no conflict of interest. The founding sponsors had no role in the design of the study; in the collection, analyses, or interpretation of data; in the writing of the manuscript, and in the decision to publish the results.

\section{AUTHORS' CONTRIBUTIONS}

All authors contributed equally for the conception and writing of the manuscript. All authors critically revised the manuscript and approved of the final version.

\section{REFERENCES}

BASNAYAKE, S.W.V, et al. Embryogenic callus proliferation and regeneration conditions for genetic transformation of diverse sugarcane cultivars. Plant Cell Rep, v.30, p.439-448, 2011. Available from: https://www.ncbi.nlm.nih.gov/pubmed/20978767. Accessed: Mar. 22, 2016. doi: 10.1007/s00299-010-0927-4.

CHEN, J.T, CHANG, W.C. Direct somtic embryogenesis and plant regeneration from leaf explants of Phalaenopsis amabilis. Biologia 
Plantarum, v.50, P.169-173, 2006. Available from: <https://link. springer.com/article/10.1007/s10535-006-0002-8>. Accessed: Feb. 03, 2017. doi: 10.1007/s10535-006-0002-8.

FENG, J.H., CHEN, J.T. A NOVEL IN VITRO PROTOCOL FOR INDUCNG DIRECT SOMATIC EMBRYOGENESIS IN PHALAEOPSIS APHRODITE WITHOUT TAKING EXPLANTS. THE SCIENTIFIC WORLD JOURNAL, V.201, P.1-7, 2014. Available from: <https://www.hindawi.com/ journals/tswj/2014/263642/>. Accessed: Feb. 10, 2017. doi: $10.1155 / 2014 / 263642$.

FREITAS, M.E., et al. Propagação in vitro de Cattleya Intermedia Graham Ex Hook (Orchidaceae) em diferentes meios de cultura. Caderno pedagógico, v.11, p.30-41, 2014.

GOW, W.-P., et al. Enhancement of direct somatic embryogenesis and plantlet growth from leaf explants of Phalaenopsis by adjusting culture period and explant length. Acta Physiol Plant, v.32, p. 621-627, 2010. Available from: <https://link.springer.com/ article/10.1007/s11738-009-0438-5>. Accessed: Jun. 19, 2017. doi: 10.1007/s11738-009-0438-5

GRANDO, M.F., et al. Immature tassels as alternative explants in somatic embryogenesis and plant regeneration in south Brazilian maize genotypes. Acta Sci Agron v.35, p. 39-47, 2013. Available from: $\quad<$ http://www.scielo.br/scielo.php?script=sci arttext\&pid $=$ S1807-86212013000100005 $>$. Accessed: Jun. 30, 2017. doi: 10.4025/actasciagron.v35i1.15545.

MINAMIGUCHI, J., MACHADO NETO, N.B. Embriogênese somática direta em folhas de Phalaenopsis: Orquidaceae. Colloq Agra v.3, p.7-13, 2007. Available from: $<$ http://agris.fao.org/agrissearch/search.do?recordID=BR2013800021>. Accessed: Mar. 25, 2018. doi: 10.5747/ca.2007.v03.n1.a22.

MOURA, L.C., et al. Effects of explant type, culture media and picloram and dicamba growth regulators on induction and proliferation of somatic embryos in Eucalyptus grandis $\mathrm{x} E$. Urophylla. Revista Árvore, v.41:e410502, 2017. Available from: $\quad<\mathrm{http}: / /$ www.scielo.br/scielo.php?script=sci_arttext\&pid $=$ S0100-67622017000500202 $>$. Accessed: Dec. 25, 2017. doi: $10.1590 / 1806-90882017000500002$.

MORADI, S., et al. Direct somatic embryogenesis in Epipactis veratrifolia, a temperate terrestrial orchid. J Hortic Sci Biotechnol v.92,p.88-97,2017. Available from: $<$ https://www.tandfonline.com/ doi/abs/10.1080/14620316.2016.1228434? journalCode=thsb20>. Accessed: Nov. 01, 2017. doi: 10.1080/14620316.2016.1228434.

NG, C.Y., SALEH, N.M. In vitro propagation of Paphiopedilum orchid through formation of protocorm-like bodies. PCTOC, v.105, p.193-202, 2011. Available from: $<$ https://link.springer. com/article/10.1007/s11240-010-9851-0>. Accessed: Mar. 01, 2017. doi: 10.1007/s11240-010-9851-0.

PARK, N.E., et al. Breeding of Phalaenopsis 'SM 333'with mini multiple flower formation. Korean. J Hortic Sci Technol 33:149154, 2015.

SARMAH, D.,at al. A Review on: In Vitro Cloning of Orchids. Int J Curr Microbiol Appl Sci 6:1909-1927, 2017. Available from: $<$ https://www.ijcmas.com/abstractview.php?ID=4146\&vol=69-2017\&SNo=235>. Accessed: Mar. 01, 2017. doi: 10.20546/ ijcmas.2017.609.235.

STEFANELLO, S., et al. Eficiência de substratos na aclimatização de plantas de Miltonia flavescens Lindl. propagadas in vitro. Revista Brasileira de Horticultura Ornamental, v.2, p.467-476, 2009. Available from: $<$ http://periodicos.unicesumar.edu.br/index. php/rama/article/view/1180>. Accessed: Mar. 15, 2017.

SMERTENKO, A., BOZHKOV, P.V. Somatic embryogenesis: Life and death processes during apical-basal patterning. J Exp Bot, v.65, p.1343-1360, 2014. Available from: <https://www.ncbi. nlm.nih.gov/pubmed/24622953>. Accessed: Mar. 11, 2018. doi: $10.1093 / \mathrm{jxb} / \mathrm{eru} 005$.

VAN DER VYVER C. Genetic transformation of the euploid Saccharum officinarum via direct and indirect embryogenesis. Sugar Tech, v.12, p.21-25, 2010. Available from: <https://link. springer.com/article/10.1007/s12355-010-0005-9>. Accessed: Apr. 17, 2018. doi: 10.1007/s12355-010-0005-9.

ZAHARA, M., et al. The Effects of different media, sucrose concentrations and natural additives on plantlet growth of Phalaenopsis Hybrid 'Pink'. Braz Arch Biol Technol, v.60, e17160149, 2017. Available from: $<$ http://www.scielo.br/scielo.php?script $=$ sci arttext\&pid $=$ S1516-89132017000100501>. Accessed: Mar. 12, 2018. doi: 10.1590/1678-4324-2017160149. 